\title{
Cotidiano
}

\section{PSIU! COMO CHAMAR A ATENÇÃO DO ALUNO EM SALA DE AULA, SEM ATINGIR SUAS RELAÇÕES SOCIAIS}

\author{
Maria das Graças Leite dos Santos (1)
}

Quando o assunto é escola, é possível enumerar diversos problemas que estão presentes no sistema educacional. Dessa forma, a pergunta que passa a permear os pensamentos de todos os envolvidos no processo ensino/aprendizagem parece ser unânime: como melhorar o ambiente escolar na sociedade de hoje?

O passado histórico da escola mostra a maneira severa que muitos profissionais da educação conduziam os seus relacionamentos com os alunos. Reflexo de um país que passou por ditaduras militares e longos processos de redemocratização; um lugar que deveria estimular o prazer de estudantes em aprender algo novo, fazia o oposto, causando revolta e caracterizando-se como um cenário propício ao desenvolvimento de personalidades violentas.

Muitos anos se passaram e a sociedade brasileira mudou, a tecnologia avançada transformou os indivíduos em ansiosos e preocupados em seguir os padrões que são impostos por uma geração sedenta de atenção. Dessa maneira, a escola continua sendo um lugar onde crianças, adolescentes e jovens procuram não apenas aprender, mas fazer amizades e assim encontrar algum grupo social no qual se identifiquem.

Além disso, estão em busca de atenção, seja de colegas de sala, de professores ou gestores escolares. Alguns casos são mais preocupantes que outros, porém ainda é possível dizer que a escola continua sendo esse lugar de observação, já que nesse universo, muitas pessoas passam a ser alvo de grandes problemas psíquicos, o que gera distúrbios de comportamento e de personalidade.

O caso mais estudado pelos profissionais da educação e da saúde é o chamado Bullying, que no ambiente escolar está ligado às constantes agressões físicas ou verbais de colegas, assunto que vem ganhando uma repercussão maior devido a diversos atentados ocorridos pelo mundo. Porém, o Brasil estava fora dessa estimativa até pouco tempo atrás, quando um jovem invadiu sua antiga escola e matou diversos alunos, fazendo o país chorar ao ver crianças inocentes se tornarem alvo de um assassino cruel e sem piedade.

Mais uma maneira de questionar as instituições de ensino e também o papel do educador, que possui a responsabilidade de marcar a vida de um aluno, positivamente ou negativamente. Além de ser capaz de identificar os casos de agressões entre colegas, o professor deve ter cuidado para não se tornar o próprio agressor verbal.

É possível presenciar em muitas escolas do Brasil, profissionais utilizando piadas de mau gosto em sala de aula ou frases que constrangem o educando, e isso para os alunos mais problemáticos ou sensíveis, pode se tornar um motivo para associarem a escola a algo estressante, difícil e até um ambiente que retrai o indivíduo. 
Outro ponto a ser discutido é o assédio moral, ou seja, publicamente e de forma repetitiva expor o aluno como aquele que não faz nada certo, não consegue aprender e no pior caso usar aquela típica frase "ele(a) não tem jeito".

O questionamento feito agora é: quantos educadores não já passaram a fazer algo assim sem ao menos avaliarem o quanto isso pode ser prejudicial para o relacionamento dos alunos? Não há duvidas que eles são sujeitos sociais e, portanto, necessitam viver em relações, precisam de aceitação dos pais, da escola, dos amigos e também dos professores. Entretanto, a realidade das escolas públicas limita a ação desses profissionais, já que existem salas numerosas, salários reduzidos, entre outros obstáculos. Diante desse fato, como exigir do profissional uma atenção reservada para identificar os problemas emocionais dos alunos, quando ele possui uma carga horária preenchida e salas com mais de quarenta alunos?

É nesse propósito que fica óbvio a necessidade da melhoria no setor educacional, a valorização do professor, dos gestores escolares e de toda a equipe responsável por essa área. A tarefa de educar pode ser considerada a mais complexa profissão existente, mas mesmo com a certeza dessa afirmação a política do país ainda fecha os olhos para algo tão caótico como é a educação brasileira.

Apesar desse fato, os professores devem ter um devido cuidado com a maneira que se relacionam com seus alunos, tentando não intimidar cada vez mais as personalidades mais sensíveis e expostas às várias crises emocionais ou doenças sociais e mentais. Dessa maneira, uma alternativa seria praticar a tão conhecida pedagogia do afeto, onde as pesquisas de Fernando Monte Serrat evidenciam o quanto a emoção está intimamente ligada ao processo de aprendizagem.

A propósito da influência das emoções na saúde psíquica, e sem perder de vista que estamos falando em educação, é de grande relevância o estado emocional em que se encontram os professores que vivem o dia-a-dia das escolas do nosso país...Em suma, não somente as emoções dos alunos interferem no processo ensino/ aprendizagem, mas também as emoções do professor (MONTE-SERRAT, 2007. p.28).

Através dessa análise, é possível ressaltar que o estado emocional do professor é tão importante quanto o do seu aluno. Por isso, torna-se necessário questionar a forma como esses profissionais estão transmitindo seus conhecimentos e a maneira como chamam a atenção de seus alunos em sala de aula. É preciso um grande cuidado, que pode ser traduzido em uma conversa particular com o aluno, com a coordenação ou psicólogos, para saber o que está interferindo no processo de aprendizagem e por qual motivo o professor não está conseguindo conduzir uma relação de companheirismo com seus alunos.

Pesquisas mostram constantemente que, a maioria das escolas públicas do Brasil, tornou-se um ambiente estressante e desestimulante para os professores, já que muitos alunos estão mais ansiosos e preocupados com outras coisas além do seu futuro. Mesmo com tantas dificuldades, o professor precisa entender que, dependendo da forma como ele conduz sua aula, ele pode desgastar não só o seu emocional, como também daqueles que estão envolvidos na plena realização do seu trabalho.

Entretanto, é necessário destacar alguns alunos que desconcentram as aulas e insistem em desobedecer às ordens dos seus professores. Eles possuem a capacidade de fazer uma aula não acontecer. Mesmo nesse caso, não é correto intimidá-los expondo-os a alguma situação constrangedora; o ideal é questioná-los, procurar entender o seu desinteresse, pedir o auxilio da direção, dos pais e quando houver a necessidade de chamar a 
atenção deles em sala de aula, tentar pensar em uma forma descontraída ou até mesmo séria, mas sem um contexto de agressão.

Em vista desse fato, a mensagem transmitida aos profissionais ligados à educação, continua sendo avaliada por alguns como "romântica" para a situação das escolas brasileiras atuais, porém, ainda é a mais coerente que, sem amor e afeto é impossível conduzir qualquer relacionamento ou profissão, principalmente, quando exige a responsabilidade de educar alguém não apenas para seguir uma carreira, mas também para a vida.

\section{Referência:}

MONTE-SERRAT. Emoção, afeto e amor: Ingredientes do Processo Educativo. São Paulo: Editora Academia de inteligência. 2007.

\section{Sobre a Autora:}

(1) Maria das Graças Leite dos Santos é Graduada em História pela Universidade Regional do CaririUrca. Pós-graduanda em Psicologia aplicada à educação pela Universidade Regional do Cariri- Urca. E-mail: gracielyleite@ hotmail.com

\section{Como citar este artigo (Formato ISO):}

SANTOS, M.G.L. Psiu! Como chamar a atenção do aluno em sala de aula, sem atingir suas relações sociais. Id on Line Revista de Psicologia, Julho de 2011, vol.1, n.14, p.06-08. ISSN 1981-1189. 